\title{
Effects of sequential enzymatic hydrolysis on structural, bioactive and functional properties of Phaseolus lunatus protein isolate

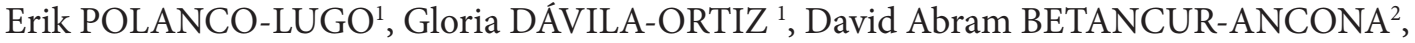 Luis Antonio CHEL-GUERRERO ${ }^{2 *}$
}

\begin{abstract}
Significant initiatives exist within the global food market to search for new, alternative protein sources with better technological, functional, and nutritional properties. Lima bean (Phaseolus lunatus L.) protein isolate was hydrolyzed using a sequential pepsinpancreatin enzymatic system. Hydrolysis was performed to produce limited (LH) and extensive hydrolysate (EH), each with different degrees of hydrolysis (DH). The effects of hydrolysis were evaluated in vitro in both hydrolysates based on structural, functional and bioactive properties. Structural properties analyzed by electrophoretic profile indicated that LH showed residual structures very similar to protein isolate (PI), although composed of mixtures of polypeptides that increased hydrophobic surface and denaturation temperature. Functionality of LH was associated with amino acid composition and hydrophobic/ hydrophilic balance, which increased solubility at values close to the isoelectric point. Foaming and emulsifying activity index values were also higher than those of PI. EH showed a structure composed of mixtures of polypeptides and peptides of low molecular weight, whose intrinsic hydrophobicity and amino acid profile values were associated with antioxidant capacity, as well as inhibiting angiotensin-converting enzyme. The results obtained indicated the potential of Phaseolus lunatus hydrolysates to be incorporated into foods to improve techno-functional properties and impart bioactive properties.
\end{abstract}

Keywords: Phaseolus lunatus; protein hydrolysate; functional properties; bioactive properties; ECA; antioxidant activity.

\section{Introduction}

New and unconventional protein sources are currently required in the food industry to provide nutritional, technological and functional properties. Legume protein has low solubility, and allergenic or anti-nutritional properties, as well as slow digestibility and assimilation (Betancur-Ancona et al., 2009; Liu et al., 2011). However, enzymatic hydrolysis is useful for modifying suitable physicochemical and sensorial properties of proteins without producing negative effects on nutritional or functional quality (Fitzgerald \& O'cuinn, 2006; Chabanon et al., 2007). Partial or extensive enzymatic hydrolysis can produce important modifications, such as a reduction in molecular size and increased hydrophobic surface, depending on the enzyme used and the degree of hydrolysis (DH) obtained (Benítez et al., 2008; Pazinatto et al., 2013). Limited hydrolysis (<10 DH) improves functional properties by enhancing solubility and associated surface properties related to the feasibility of the formation and stabilization of air-water and oil-water interfaces, which are important properties in food product applications (Larré et al., 2006). Extended hydrolysis (> $10 \mathrm{DH}$ ) provides nutritional and therapeutic properties, based on the absorption of peptides with a wide range of biological activities, including antimicrobial, antioxidant, immunomodulatory, antithrombotic and antihypertensive effects (Mulero et al., 2011). Antioxidant peptides may function by preventing and reducing oxidative stress in cells, thereby promoting the prevention of diabetes, cancer, and cardiovascular and inflammatory diseases (Zhang et al., 2008). Antihypertensive peptides inhibit angiotensin-converting enzyme (ACE) activity, which is responsible for increasing vascular resistance and fluid volume, associated with increased risk of cardiovascular and chronic degenerative diseases (Chen et al., 2009; Mulero et al., 2011). ACE inhibitory peptides and those that promote antioxidation have been obtained from different sources, although in minor proportions from legumes. Amongst underutilized sources, lima bean "ib" (Phaseolus lunatus) is a promising source of protein hydrolysates for incorporation as ingredients in industrial food systems due to its amino acid composition, which contributes to promoting bio-functional, technological and nutritional properties. The objectives of this study were: 1) to evaluate structural and functional properties of limited hydrolysate; and 2) to determine bioactive and structural properties of extensive hydrolysate.

\section{Materials and methods}

\subsection{Materials}

Phaseolus lunatus seeds were obtained from a local market in Mérida, Yucatán, Mexico. The enzymes used were Pepsin ${ }^{\circledR}$ (P7000), a peptidase from porcine gastric mucosa with specific activity $\geq 250 \mathrm{U} / \mathrm{mg}$; and Pancreatin ${ }^{\circledR}$ (P3292), a mixture of several digestive enzymes produced by the exocrine cells of the porcine pancreas, with a protease activity $\geq 100 \mathrm{U} / \mathrm{mg}$. The enzymes and standards were provided by Sigma-Aldrich (Sigma Chemical Co., St. Louis, MO, USA). All other chemicals were of reagent grade, provided by JT Baker (Phillipsburg, NJ, USA) and Merck (Darmstadt, Germany). 


\subsection{Protein isolate (PI) and hydrolysate}

PI was obtained following the wet division and isoelectric precipitation method (Chel-Guerrero et al., 2002). P. lunatus flour was dispersed in distilled water at a ratio of $1: 6(\mathrm{w} / \mathrm{v})$, the $\mathrm{pH}$ was adjusted to 11 with $1 \mathrm{~N} \mathrm{NaOH}$, and the dispersion was stirred for $1 \mathrm{~h}$ at $400 \mathrm{rpm}$ (Heidolph, Silent Crusher RZ-1, Schwabach, Germany). Afterwards, the dispersion was sequentially filtered through $80(177 \mu \mathrm{m}), 100(147 \mu \mathrm{m})$ and $200(74 \mu \mathrm{m})$ stainless steel mesh. Soluble protein was recovered by decantation and the $\mathrm{pH}$ was adjusted to the isoelectric point (4.5) with $1 \mathrm{~N} \mathrm{HCl}$. Finally, the solution was centrifuged at $1317 \mathrm{x} \mathrm{g}$ for $12 \mathrm{~min}$ (Mistral 3000i, Curtin Matheson Sci., Houston TX), and the precipitate was dried at $-47^{\circ} \mathrm{C}$ and $13 \times 10^{-3} \mathrm{mbar}$. The chemical composition of the isolate was determined according to AOAC procedures (Association of Official Analytical Chemists, 1997). PI was hydrolyzed by sequential enzymatic digestion in vitro using pepsin-pancreatin (Megías et al., 2004). Hydrolysis parameters were protein isolate dispersion in water $(4 \% \mathrm{w} / \mathrm{v})$; enzyme/substrate ratio (1:50 v/v); Pepsin ( $\mathrm{pH} 2)$; Pancreatin $(\mathrm{pH} 7.5)$; and temperature $\left(37^{\circ} \mathrm{C}\right)$. The enzymatic reaction was stopped by heating to $80^{\circ} \mathrm{C} / 20 \mathrm{~min}$. The supernatant was separated by centrifugation at $13211 \times \mathrm{g}$ for $20 \mathrm{~min}$ at $4{ }^{\circ} \mathrm{C}$ (Beckman) and dried in a lyophilizer (Labconco) for subsequent analysis. Reaction times were $10 \mathrm{~min}$ for limited hydrolysate (LH) and $60 \mathrm{~min}$ for extensive hydrolysate (EH). Prepared dispersions for $\mathrm{LH}$ and $\mathrm{EH}$ used a 1 and $4 \%(\mathrm{w} / \mathrm{v})$ enzyme ratio respectively.

\subsection{Degree of hydrolysis (DH)}

DH was calculated by determining free amino groups with OPA following the spectrophotometric method (Nielsen et al., 2001). The total number of amino groups was determined in a sample of protein isolate that was completely hydrolyzed with $6 \mathrm{~N} \mathrm{HCl}$ in a vacuum oven at $120^{\circ} \mathrm{C}$ for $24 \mathrm{~h}$.

\subsection{Structural properties}

The following structural properties were determined for PI, $\mathrm{EH}$ and LH: molecular weight profile, amino acid composition, surface hydrophobicity, and calorimetric profile.

\section{Electrophoresis (SDS-PAGE)}

The molecular weight profile was determined by denaturing electrophoresis in polyacrylamide gel at 10 and 15\% (Schagger \& Von Jagow, 1987). The gels were run in a mini-PROTEAN II Systems electrophoresis chamber (Bio-Rad) at $110 \mathrm{~V}$ and $40 \mathrm{~mA} /$ gel for 3 hours. Low Range protein molecular weight standards (Cat 161-0305) and Kaleidoscope Polypeptide (Cat 161-0325) from Bio-Rad were used. Gels were stained with Coomassie blue $(0.01 \%)$ and gel image analysis was performed using Quantity One Analysis version 4.6.1 (Bio-Rad Richmond, CA, USA).

\section{Amino acid composition}

Amino acids were determined by High Performance Liquid Chromatography (HPLC) according to Alaiz et al. (1992). The samples were hydrolyzed with $6 \mathrm{~N} \mathrm{HCl}$ for $24 \mathrm{~h}$ at $110{ }^{\circ} \mathrm{C}$ in sealed vials maintained under inert atmosphere $\left(\mathrm{N}_{2}\right)$. Amino acid composition was determined using an HPLC system (Agilent 1100 series) and a reverse phase column (NovaEmbalar C 18, 4mm, Waters, $300 \mathrm{~mm} \times 3.9 \mathrm{~mm}$ ) at $18^{\circ} \mathrm{C}$. The solvent used was sodium acetate $(25 \mathrm{mM})$, containing sodium azide $(0.02 \%)$ at $\mathrm{pH} 6$ in acetonitrile at a flow rate of $0.9 \mathrm{~mL} / \mathrm{min}$. Tryptophan was determined at $280 \mathrm{~nm}$ after basic hydrolysis with $4 \mathrm{M} \mathrm{NaOH}$ for $4 \mathrm{~h}$ at $110^{\circ} \mathrm{C}$.

\section{Extrinsic and intrinsic hydrophobicity}

Extrinsic hydrophobicity was determined using the fluorescence technique and 1-aniline-8-naphthalene-sulfonate (ANS) as the probe (Kato \& Nakai, 1980). Serial protein dilutions (0.05-0.5 $\left.\mathrm{mg} \mathrm{mL}^{-1}\right)$ were prepared in $10 \mathrm{mM}$ phosphate buffer $(\mathrm{pH} 7)$. The ANS solution in the same buffer was prepared before measurement. Thirty microliters of ANS $\left(8 \times 10^{-3} \mathrm{M}\right)$ were added to $4 \mathrm{~mL}$ of each dilution. Fluorescence intensity (FI) was measured at $264 \mathrm{~nm}$ (excitation) and $484 \mathrm{~nm}$ (emission) at $25{ }^{\circ} \mathrm{C}$ with a light attenuator using a Perkin-Elmer 2000 fluorometer (Perkin-Elmer Corp. Norwalk, CT, USA). The protein hydrophobicity index was calculated by the initial FI slope vs. protein concentration plot (calculated by linear regression analysis).

The intrinsic hydrophobicity of protein samples was determined according to Liu et al. (2011). Stock protein solutions $\left(0.15 \mathrm{mg} \mathrm{mL}^{-1}\right)$ were prepared in $10 \mathrm{mM}$ phosphate buffer ( $\mathrm{pH}$ 7). Protein solutions with ANS were excited at $290 \mathrm{~nm}$, and the emission spectrum was obtained by scanning from 300 to $400 \mathrm{~nm}$. Intrinsic fluorescence emission spectra were analyzed by the equipment software (FL WINLAB version 4.00.02) based on the fluorescence intensity and emission wavelength.

\section{Differential Scanning Calorimetry (DSC)}

Calorimetric profile was determined (Liu et al., 2011) from protein dispersion at $20 \%(\mathrm{w} / \mathrm{v})$ in $10 \mathrm{mM}$ phosphate buffer $(\mathrm{pH} 7)$ and deposited on hermetically sealed aluminum plates. An empty plate was used as reference. Thermal transitions were determined in a differential scanning calorimeter (Perkin-Elmer DSC-6, Norwalk, CT) over a range of 30 to $120^{\circ} \mathrm{C}$ with a flux of $10{ }^{\circ} \mathrm{C} / \mathrm{min}$ in inert atmosphere at $20 \mathrm{~mL} \mathrm{~min}{ }^{-1}$. Peaks or denatured temperatures $(\mathrm{Td})$ and enthalpy changes $(\Delta \mathrm{H})$ were analyzed by the equipment software (Pyris version 6 ).

\subsection{Bioactive properties}

In order to evaluate the bioactivities for PI and EH, ACE-I and antioxidant activity analyses were performed.

\section{Angiotensin-Converting Enzyme Inhibitory Activity (ACE-I)}

Preparation of ACE-I and the inhibition assay were carried out according Cian et al. (2011). The ACE-I inhibition assay was performed with the colorimetric reaction of hippuric acid (HHL) and 2,4,6-trichloro-1,3,5-triazine (TT). This reaction proceeded during $45 \mathrm{~min}$ at $37^{\circ} \mathrm{C}$ and was performed as follows: $175 \mu \mathrm{L}$ of $0.1 \mathrm{M}$ potassium phosphate buffer ( $\mathrm{pH} 8.3$ ), $15 \mu \mathrm{L}$ of 
$5 \mathrm{M} \mathrm{NaCl}, 20 \mu \mathrm{L}$ of HHL $\left(3.3 \mathrm{~g} \mathrm{~L}^{-1}\right), 20 \mu \mathrm{L}$ of enzyme extract and different amounts of hydrolysate extracts were mixed. The reaction was stopped with $665 \mu \mathrm{L}$ of TT $\left(30 \mathrm{~g} \mathrm{~L}^{-1}\right)$ in dioxane. Finally, reaction mixtures were centrifuged at $12,000 \times \mathrm{g}$ for 10 minutes, and ACE-I inhibition (\%) was determined at $382 \mathrm{~nm}$. Determination of $\mathrm{IC}_{50}$ was performed by plotting log concentration of hydrolyzed protein $\left(\mathrm{mg} \mathrm{mL}^{-1}\right)$ vs. percentage of ACE-I activity.

\section{Antioxidant activity}

Antioxidant activity was determined from the reduction of cation radical $\mathrm{ABTS}^{+}$and TROLOX as standard (Pukalskas et al., 2002). Radical preparation was carried out from the reaction of $\mathrm{ABTS}^{+}\left(10 \mathrm{~mL}, 2 \mathrm{mmol} \cdot \mathrm{L}^{-1}\right)$ dissolved in phosphate buffered saline $\left(0.1 \mathrm{mmol} \cdot \mathrm{L}^{-1}, \mathrm{pH} 7.4\right)$ and $\mathrm{Na}_{2} \mathrm{~S}_{2} \mathrm{O}_{8}(40 \mu \mathrm{L}$, $\left.70 \mathrm{mmol} \cdot \mathrm{L}^{-1}\right)$. Mixtures were incubated in the dark at room temperature for $16 \mathrm{~h}$ before use. $\mathrm{ABTS}^{+}$solution was diluted with phosphate buffered saline until $0.8+0.03$ at $734 \mathrm{~nm}$. Aliquots from samples were mixed with $990 \mu \mathrm{L}$ of diluted $\mathrm{ABTS}^{+}$solution and absorbance was read at $734 \mathrm{~nm}$. TROLOX equivalent antioxidant capacity (TEAC) was estimated from the concentration-response curve for $\mathrm{ABTS}^{+}$absorbance at $734 \mathrm{~nm}$ as a function of the concentration of standard solutions of TROLOX (0-2.5 $\left.\mathrm{mmol} \mathrm{L}{ }^{-1}\right)$ diluted in $0.01 \mathrm{mmol} \cdot \mathrm{L}^{-1}$ phosphate buffered saline. Absorbance was determined $6 \mathrm{~min}$ after final mixing.

\subsection{Functional properties}

Solubility, foam capacity and stability, and emulsifying activity and stability were determined for PI and LH to evaluate their functional properties.

\section{Solubility}

Solubility profile was performed according to Were et al. (1997). Sample dispersions (0.5\% w/v) were maintained under constant agitation for 30 minutes and adjusted to the $\mathrm{pH}$ studied $(2,4,6,8$ and 10). Dispersions were centrifuged at $4320 \mathrm{x} g$ for 30 minutes at $4{ }^{\circ} \mathrm{C}$. Nitrogen content in the supernatant was determined by the Kjendahl method (Association of Official Analytical Chemists, 1997). Solubility was expressed as g soluble protein $100 \mathrm{~g}^{-1}$ of sample.

\section{Foam Capacity (FC) and Foam Stability (FS)}

These properties were evaluated from suspensions $(100 \mathrm{~mL})$ of sample (1.5\% w/v) adjusted to $\mathrm{pH} 2,4,6,8$ and 10 (Chau et al., 1997). Suspensions were mixed and beaten at low speed. They were then transferred to a $250 \mathrm{~mL}$ graduated cylinder. Foam capacity (FC) was expressed as the increase in percentage of foam volume measured after 30 seconds. Foam stability (FS) was expressed as residual foam volume at 5, 30 and 120 minutes after blending.

\section{Emulsifying Activity Index (EAI)}

Emulsifying properties were evaluated according to Pearce \& Kinsella (1997). Protein solutions (1\% w/v) and corn oil
$(10 \mathrm{~mL})$ with $\mathrm{pH}$ adjusted to $2,4,6,8$ and 10 were added to tubes and mixed at 20,000 rpm for $1 \mathrm{~min}$ in a Stir-Pak ${ }^{\circledR}$ Mixer System (50002-30, Cole Parmer Instrument Company, USA) for emulsion formation. An aliquot of $50 \mu \mathrm{L}$ was taken from the bottom of the tube and diluted in $5 \mathrm{~mL}$ of $0.1 \%(\mathrm{w} / \mathrm{v})$ sodium dodecyl sulfate solution. Absorbance was measured immediately (0 minutes) at $500 \mathrm{~nm}$ in a spectrophotometer (Jenway model 6305, Barloword Scientific, UK). The absorbance was used to determine the EAI of the protein.

\subsection{Statistical analysis}

All experiments were carried out in triplicate, and results were expressed as mean values. Data were analyzed using statistical one-way analysis of variance (ANOVA). For foaming and emulsification data, two-way ANOVA was used. Least significant differences (LSD) between means were identified using Statgraphics Plus version 5.1 software (Statpoint Technologies Inc., VA, USA).

\section{Results and discussion}

\subsection{Degree of Hydrolysis (DH)}

The chemical composition of PI obtained by alkaline extraction and isoelectric precipitation is a rich source of protein

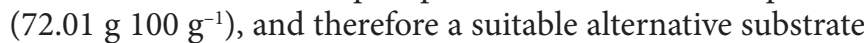
for obtaining limited $(<10 \% \mathrm{DH})$ and extensive hydrolysate ( $>10 \% \mathrm{DH})$. The sequential action of enzymatic digestion with pepsin-pancreatin produced hydrolysates with DHs of $1.7 \%$ (LH) and $15.97 \%(\mathrm{EH})$. The synergistic effect of the enzymes used (endopeptidase and exopeptidase) probably allowed for the generation of a mixture of polypeptides and peptides, with an increased exposure of amino and carboxyl-terminal aromatic amino acid residues (Yang et al., 2004) and carboxyl groups of lysine or arginine residues (Benítez et al., 2008).

\subsection{Structural properties}

\section{Electrophoresis (SDS-PAGE)}

The electrophoretic profile of PI was divided into regions with high $(105.1,77.2 \mathrm{kDa})$, intermediate $(62.6,58.8,50.5$, $46.9 \mathrm{kDa})$ and low molecular weights $(36.0,34.0,31.0,22.5$ $\mathrm{kDa})$, associated with typical bands corresponding to vicilin (7S fraction) and legumin (11S fraction) subunits and polypeptides (Chel-Guerrero et al., 2007). The polypeptides of $7 \mathrm{~S}$ and $11 \mathrm{~S}$ fractions exhibit different susceptibilities to hydrolysis due to their different aggregation forms, caused by structural native conformation of globulins (Kain et al., 2009; Chel-Guerrero et al., 2011). According to Molina \& Añon (2001), who investigated hydrolyzed soy, large increases in the intensity of some bands for LH were probably related to hydrolysis of the most exposed areas of the polypeptides. In this study, limited hydrolysis generated intense bands at 106.9, $77.2,56.1,35.6,30.5$ and $21.4 \mathrm{kDa}$. The electrophoretic pattern in $\mathrm{EH}$ showed polypeptides and peptides of lower molecular weight: intense bands at 21.3, 10.7 and $7.1 \mathrm{kDa}$, and less intense at $34.6,32.9,31.9$ and $30.2 \mathrm{kDa}$ (Figure 1). Given that bitterness 
intensity depends on the degree of hydrolysis of proteins and hydrophobic amino acid content, the polypeptides and peptides obtained had a greater molecular weight than that required to interact with bitter-taste receptors in the oral cavity (Fitzgerald \& O'cuinn, 2006). They would therefore be suitable as potential food ingredients.

\section{Amino acid profile}

Amino acid composition of EH and LH showed significant differences $(\mathrm{p}<0.05)$ with respect to PI, indicating that enzymatic hydrolysis may alter the nutritional value of the original protein and improve its digestibility. It is important to highlight that both hydrolysates in this study exhibited higher values than the human protein standard for infant nutrition (Food and Agriculture Organization \& World Health Organization, 2007), except for sulfur amino acids. The amino acid composition of LH indicated that it possesses high proportions of Asp and Glu, which are usually storage proteins of legumes (Table 1). The charges of the amino acids present in LH suggest a positive effect on hydrophobic-hydrophilic balance, which in turn promotes improved solubility and functional properties (Larré et al., 2006). EH showed considerable hydrophobic amino acid content, such as Trp, Phe, Pro, Tyr, Val, and Ile, which are usually associated with ACE inhibiting activities (Megías et al.,

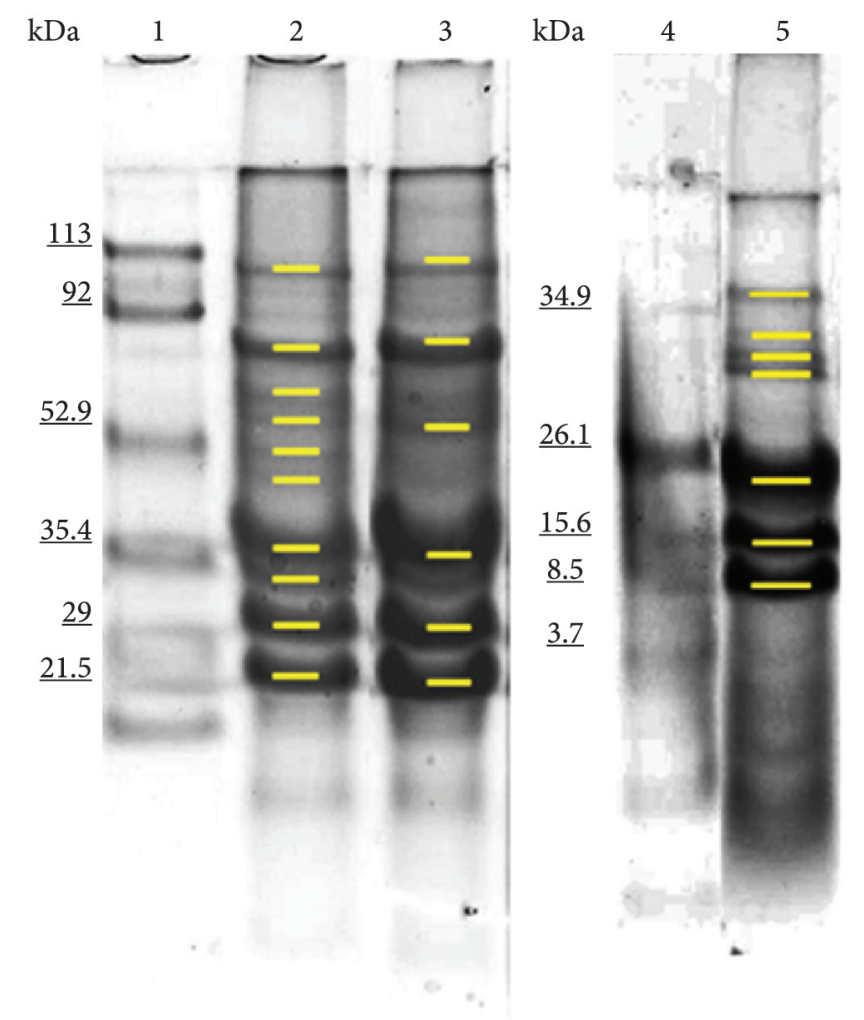

Figure 1. Electrophoretic profile (SDS-PAGE) of protein isolate (PI), extensive (EH) and limited hydrolysate (LH) of P. lunatus. Line 1, High molecular weight protein standard; Line 2, PI; Line 3, LH; Line 4, Low molecular weight protein standard; Line 5, EH.
2004; Cheung et al., 1980). Meanwhile, His, Ala, Leu, Met and those described above (Tyr, Pro, Ile, Val) (Table 1) are related to antioxidant activities (Adebiyi et al., 2009; Zhao et al., 2012). These amino acids suggest that the aforementioned bioactivities may be present in $\mathrm{EH}$.

\section{Extrinsic and intrinsic hydrophobicity}

The values obtained for the extrinsic hydrophobicity of EH (11.71) and LH (24.94) were statistically different ( $\mathrm{p}<0.05)$, indicating that enzymatic modification allowed greater exposure to hydrophobic groups that were initially hidden in PI (4.62). Moreover, it is important to note that inverted values between extrinsic hydrophobicity and $\mathrm{DH}$ were obtained in this study, due to the formation of aggregates or the increased flexibility of peptides, which allowed them to adopt a conformation with a greater or lesser exposure of hydrophobic groups (Liu et al., 2010). The emission spectrum of intrinsic fluorescence in LH indicated that an apparent reduction of tertiary conformational structure occurs at neutral pH values (Zhao et al., 2011), with increased flexibility of modified molecules. In $\mathrm{EH}$, meanwhile, greater exposure of aromatic amino acid residues (Trp and Tyr) or interactions (Trp-Tyr) occurred in a hydrophilic environment, indicating the existence of greater changes in conformation of polypeptides (Figure 2). The high exposure of hydrophobic amino acid residues in $\mathrm{EH}$ may have an impact on antioxidant activity, and therefore on suitable incorporation into emulsions to inhibit lipid oxidation (Cheng et al., 2010) or encapsulation of protein hydrolysates for antihypertensive effects (Ruiz-Ruiz et al., 2013a).

Table 1. Amino acid composition of protein isolate (PI) and extensive (EH) and limited hydrolysate (LH) of P. lunatus.

\begin{tabular}{|c|c|c|c|c|}
\hline \multirow{2}{*}{ Amino acid } & \multicolumn{3}{|c|}{ Content (g $100 \mathrm{~g}^{-1}$ of protein) } & \multirow[b]{3}{*}{ FAO } \\
\hline & PI & LH & $\mathrm{EH}$ & \\
\hline Essential & & & & \\
\hline Lysine & $6.0 \pm 0.1^{\mathrm{a}}$ & $6.1 \pm 0.1^{\mathrm{a}}$ & $5.9 \pm 0.1^{\mathrm{a}}$ & 5.20 \\
\hline Tryptophan & $1.0 \pm 0.0^{\mathrm{a}}$ & $0.8 \pm 0.0^{\mathrm{b}}$ & $0.8 \pm 0.0^{\mathrm{b}}$ & 0.74 \\
\hline Phenylalanine & $0.5 \pm 0.0^{\mathrm{a}}$ & $4.9 \pm 0.1^{\mathrm{a}}$ & $5.0 \pm 0.0^{\mathrm{a}}$ & $4.60^{1}$ \\
\hline Tyrosine & $3.6 \pm 0.1^{\mathrm{a}}$ & $2.9 \pm 0.0^{\mathrm{b}}$ & $2.8 \pm 0.1^{\mathrm{b}}$ & \\
\hline Methionine & $0.4 \pm 0.0^{\mathrm{b}}$ & $0.3 \pm 0.1^{\mathrm{b}}$ & $0.6 \pm 0.1^{\mathrm{a}}$ & $2.60^{2}$ \\
\hline Cysteine & $3.9 \pm 0.0^{\mathrm{a}}$ & $0.1 \pm 0.0^{\mathrm{b}}$ & $0.1 \pm 0.0^{\mathrm{b}}$ & \\
\hline Threonine & $4.4 \pm 0.0^{\mathrm{b}}$ & $6.5 \pm 0.1^{\mathrm{a}}$ & $6.4 \pm 0.0^{\mathrm{a}}$ & 2.7 \\
\hline Leucine & $9.2 \pm 0.1^{\mathrm{a}}$ & $8.3 \pm 0.0^{b}$ & $8.4 \pm 0.1^{\mathrm{b}}$ & 6.30 \\
\hline Isoleucine & $4.3 \pm 0.0^{\mathrm{a}}$ & $3.9 \pm 0.0^{\mathrm{b}}$ & $3.9 \pm 0.2^{\mathrm{b}}$ & 3.10 \\
\hline Valine & $4.8 \pm 0.0^{c}$ & $6.4 \pm 0.0^{\mathrm{a}}$ & $6.3 \pm 0.0^{\mathrm{b}}$ & 4.20 \\
\hline \multicolumn{5}{|l|}{ Non essential } \\
\hline Aspartic acid ${ }^{3}$ & $12.8 \pm 0.2^{\mathrm{a}}$ & $12.5 \pm 0.0^{\mathrm{b}}$ & $12.3 \pm 0.0^{c}$ & \\
\hline Glutamic acid ${ }^{4}$ & $15.0 \pm 0.2^{\mathrm{a}}$ & $12.1 \pm 0.1^{\mathrm{c}}$ & $12.5 \pm 0.1^{\mathrm{b}}$ & \\
\hline Serine & $7.4 \pm 0.0^{\mathrm{a}}$ & $6.9 \pm 0.0^{\mathrm{b}}$ & $6.3 \pm 0.0^{c}$ & \\
\hline Histidine & $3.2 \pm 0.0^{\mathrm{a}}$ & $1.4 \pm 0.1^{\mathrm{b}}$ & $1.4 \pm 0.0^{\mathrm{b}}$ & \\
\hline Arginine & $5.0 \pm 0.0^{c}$ & $7.0 \pm 0.0^{\mathrm{b}}$ & $7.3 \pm 0.0^{\mathrm{a}}$ & \\
\hline Alanine & $6.1 \pm 0.1^{\mathrm{c}}$ & $8.4 \pm 0.0^{\mathrm{b}}$ & $9.0 \pm 0.1^{\mathrm{a}}$ & \\
\hline Proline & $7.7 \pm 0.1^{\mathrm{a}}$ & $3.9 \pm 0.0^{\mathrm{b}}$ & $3.7 \pm 0.1^{\mathrm{c}}$ & \\
\hline Glycine & $4.7 \pm 0.0^{c}$ & $7.6 \pm 0.2^{\mathrm{a}}$ & $7.3 \pm 0.0^{\mathrm{b}}$ & \\
\hline
\end{tabular}

${ }^{1}$ Phenylalanine + Tyrosine; ${ }^{2}$ Methionine + Cysteine; ${ }^{3}$ Aspartic acid + Asparagine; ${ }^{4}$ Glutamic acid + Glutamine. ${ }^{\text {ahh }}$ Different letters indicate significant differences $(\mathrm{p}<0.05)$. Data are the means of three determinations. 


\section{Thermal properties}

The thermal profile of PI showed endothermic transitions at $96.07{ }^{\circ} \mathrm{C}$ and $104.06{ }^{\circ} \mathrm{C}$, which correspond to thermal denaturation of $7 \mathrm{~S}$ and $11 \mathrm{~S}$ globulin fractions respectively (total $\Delta \mathrm{H} 12.66 \mathrm{~J} \mathrm{~g}^{-1}$ ), as reported previously (Chel-Guerrero et al., 2011). Moreover, the hydrolysates showed different values $(\mathrm{p}<0.05)$. The LH thermogram showed a single peak at $98.41{ }^{\circ} \mathrm{C}\left(\Delta \mathrm{H} 10.27 \mathrm{~J} \mathrm{~g}^{-1}\right)$, while $\mathrm{EH}$ showed a lower enthalpy $\left(\Delta \mathrm{H} 3.52 \mathrm{~J} \mathrm{~g}^{-1}\right)$ at $95.41{ }^{\circ} \mathrm{C}$ (Figure 3). In this regard, $\mathrm{LH}$ thermal stability associated with the denaturation temperature of globular proteins suggests the existence of polypeptides with more compact tertiary conformation (Tang \& Sun, 2011; Zhao et al., 2011). In the case of $\mathrm{EH}$, lower enthalpy values are representative of a structure that is less ordered (hydrogen bonds breaking) and more susceptible to heat or enzymatic treatments (Zhao et al., 2011; Guimarães et al., 2012). Results obtained for the thermal properties evaluated were correlated with those obtained by electrophoretic profile assays.

\subsection{Bioactive properties}

\section{Inhibition of ACE-I}

ACE inhibitory properties in bioactive peptides are attractive due to their beneficial effects as physiological modulators of metabolism associated with hypertension and

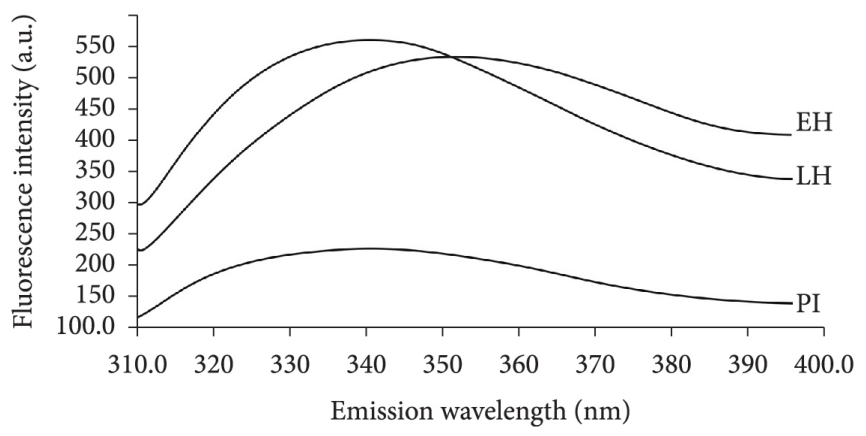

Figure 2. Intrinsic fluorescence spectroscopy of protein isolate (PI), extensive (EH) and limited hydrolysate (LH) of P. lunatus.

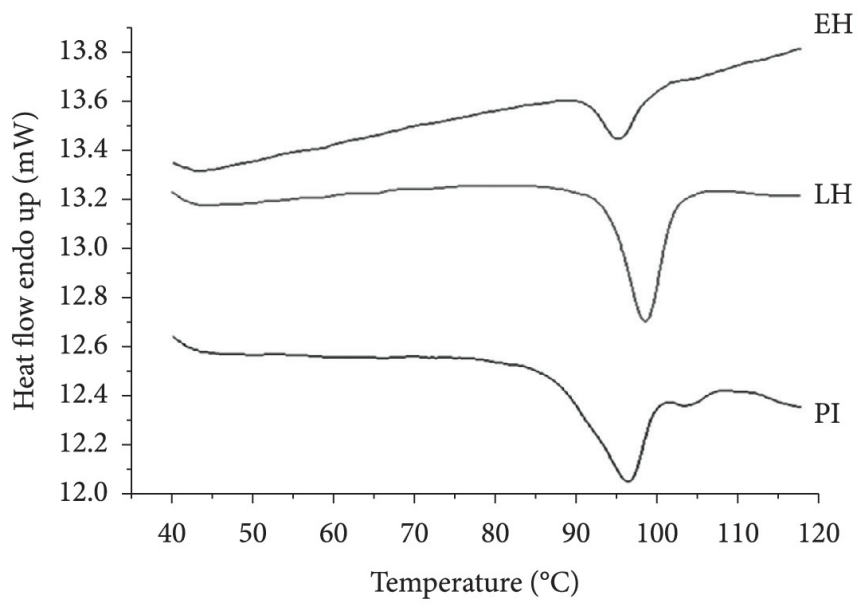

Figure 3. Thermal profile of protein isolate (PI), extensive (EH) and limited hydrolysate (LH) of P. lunatus. atherosclerosis (Chen et al., 2009). In the case of PI, ACE inhibition was not detected due to the encryption of peptides in the protein (Mallikarjun et al., 2006). The $\mathrm{IC}_{50}$ for $\mathrm{EH}$ $\left(0.321 \mathrm{mg} \mathrm{mL}^{-1}\right)$ was in the range of ACE-I inhibition reported for enzymatic hydrolysates from different plant sources ( IC $_{50}$ 0.180-5.4 mg mL $\mathrm{m}^{-1}$ ) (Yust et al., 2003; Ruiz-Ruiz et al., 2013b). In this regard, the $\mathrm{IC}_{50}$ of $\mathrm{EH}$ was not dependent on higher $\mathrm{DH}$; rather it depended on the peptide mixture resulting from the application of sequential hydrolysis, whose structural patterns allowed for interaction with active ACE sites (Li et al., 2005). Therefore, the potential inhibition of ACE in EH was promoted by the amino acid composition of the residues (Phe, Tyr, Pro), which are preferably associated with the last three positions of the C-terminal region (Torruco-Uco et al., 2009; Cheung et al., 1980) and N-terminal (Val, Ile), contributing significantly to ACE inhibitory activity.

\section{Antioxidant activity}

The TEAC obtained from EH was $13.20 \mathrm{mM} \mathrm{mg}^{-1}$ protein. This value was significantly higher $(\mathrm{p}<0.05)$ than PI (1.44 $\mathrm{mM} \mathrm{mg}^{-1}$ protein). The antioxidant activity of $\mathrm{EH}$ was higher in comparison to hydrolysates from Flavourzyme (11.55 $\mathrm{mM} \mathrm{mg}^{-1}$ protein) and Alcalase (10.09 $\mathrm{mM} \mathrm{mg}^{-1}$ protein) of $P$. vulgaris (Torruco-Uco et al., 2009). The high TEAC value could be due to specific proteolytic activity of endoprotease used to hydrolyze vicilins, which show a more active surface (Chel-Guerrero et al., 2011) and produce mixtures of peptides of different size and amino acid composition. Moreover, the emission spectrum of intrinsic fluorescence of $\mathrm{EH}$ was indicative of changes at the level of the tertiary structure of the protein, as well as the exposure at aqueous phase of sequences with one or more amino acid residues of His, Trp, Tyr, Met, Pro, Leu, Ile, Val and Ala (Adebiyi et al., 2009). These amino acids donate protons/electrons to the deficient radicals to maintain the stability of molecular electron resonance structure, as occurs in antioxidant activity of hydrolysates of Glycine max in liposomal systems (Peña-Ramos \& Xiong, 2002) and peptide fractions of Phaseolus vulgaris (Carrasco-Castilla et al., 2012).

\subsection{Functional properties}

\section{Solubility}

The nitrogen solubility pattern in $\mathrm{LH}$ was greater than in $\mathrm{PI}$, exhibiting a marked dependence according to $\mathrm{pH}$, with minimum and maximum values at $\mathrm{pH} 4$ (26.28\%) and $\mathrm{pH} 10$ (99\%) respectively (Figure 4). This is due to the occurrence of conformational changes in the protein, caused by the effect of the endopeptidic activity of the enzymes (Benítez et al., 2008) A slight modification in molecular weights of protein chains in LH greatly promotes their solubility in aqueous medium as a result of hydrophilic/hydrophobic balance (Liu et al., 2011). Similarly, the solubility corresponded with the values obtained from DSC, as indicated by denaturation enthalpy; the solubility increased without a total loss of native state. Higher solubility of $\mathrm{LH}$ at reduced $\mathrm{pH}$ could therefore favor performance on sensory properties (little or no turbidity and little or no grittiness) (Chabanon et al., 2007). 


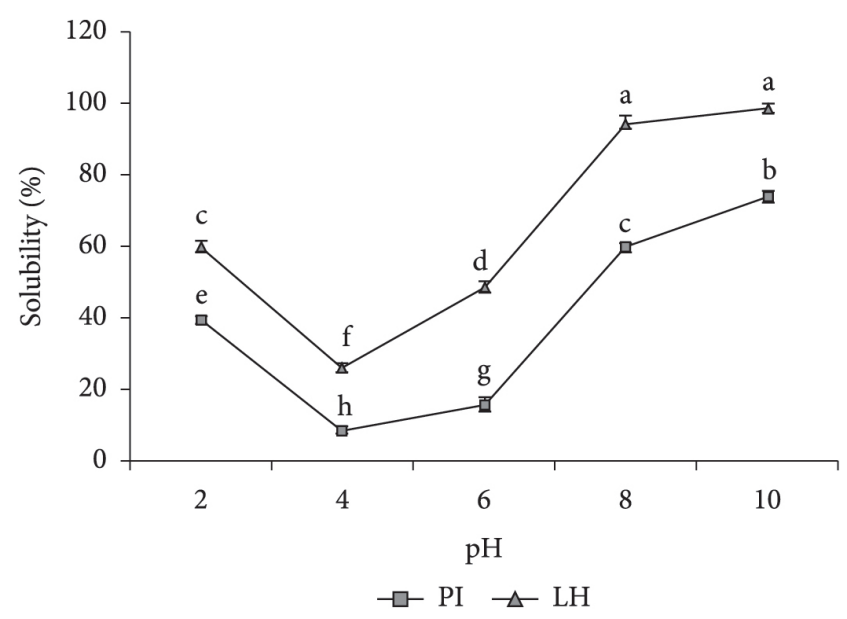

Figure 4. Solubility of nitrogen in protein isolate (PI) and limited hydrolysate $(\mathrm{LH})$ of $P$. lunatus. ${ }^{\text {a-h }}$ Different letters indicate significant differences $(\mathrm{p}<0.05)$. Data are the means of three determinations.

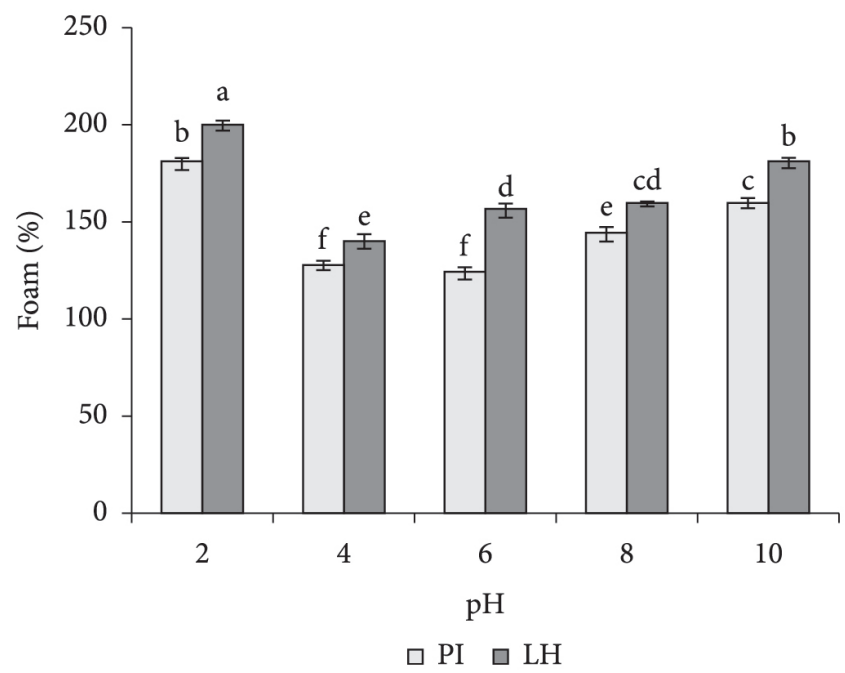

Figure 5. Foam capacity of protein isolate (PI) and limited hydrolysate (LH) of $P$. lunatus. ${ }^{\text {a-f }}$ Different letters indicate significant difference $(\mathrm{p}<0.05)$. Data are the mean of three determinations.

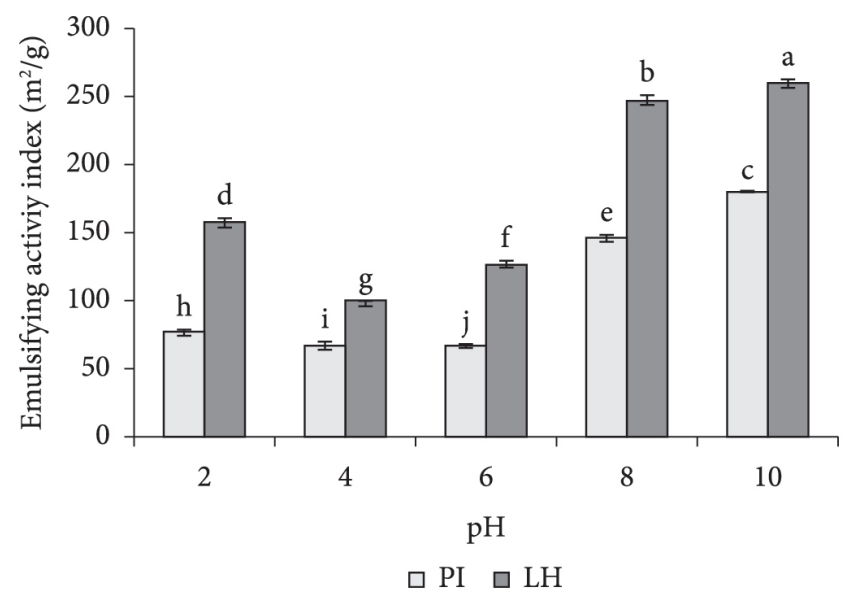

Figure 6. Emulsifying activity index of protein isolate (PI) and limited hydrolysate $(\mathrm{LH})$ of $P$. lunatus. ${ }^{\mathrm{a}-\mathrm{i}}$ Different letters indicate significant difference $(\mathrm{p}<0.05)$. Data are the mean of three determinations.

\section{Foam capacity and foam stability}

For LH, foam capacity showed values between 200 and $145 \%$ at the tested pHs. Meanwhile, values obtained from PI were lower at $\mathrm{pH} 4(128 \%)$ and 6 (124\%) (Figure 5). Analysis of variance of the data indicated that $\mathrm{pH}$ and protein sample, as well as an interaction between these factors, had a significant influence $(\mathrm{p}<0.05)$ on foam capacity. Solubility and foam capacity are associated with each other, and are also related to charge and hydrophobicity of polypeptides (Damodaran, 1994). The affinity to the interface and the rapid rate of adsorption of LH were probably favored by the amino acid composition and hydrophobicity shown (Kain et al., 2009). As for foam stability in $\mathrm{LH}$, this was higher at $\mathrm{pH}$ near to the isoelectric point and lower at acid and alkaline $\mathrm{pH}$ due to ionic repulsion of polypeptides. The enzymatic modification produced smaller protein chains compared to PI, which could not form flexible films around air bubbles as indicated by the lower foam stability (Komplong et al., 2007). During evaluation for $120 \mathrm{~min}$, the foam stability in LH was higher (132-124\%) at $\mathrm{pH}$ near to the isoelectric point and lower at acid (200-176\%) and alkaline (168-136\%) pH due to ionic repulsion of polypeptides. The enzymatic modification produced smaller protein chains compared to PI, which could not form flexible films around air bubbles as indicated by the lower foam stability (Komplong et al., 2007).

\section{Emulsifying Activity Index (EAI) and Emulsion Stability Index} (ESI)

The emulsifying activity of LH showed higher values (99.3$261.11 \mathrm{~m}^{2} \mathrm{~g}^{-1}$ ) than PI at the different $\mathrm{pHs}$ under study. The statistical analysis indicated that $\mathrm{pH}$ and protein sample, and an interaction between these factors, had a significant influence $(p<0.05)$ on emulsifying activity (Figure 6$)$. The increase in activity is probably due to suitable solubility of LH in the system, as well as the increased hydrophobic surface due to limited hydrolysis of the globulin structure (Tang \& Sun, 2011; Mugendi et al., 2010). This contrasted with PI, which had less interaction between non-polar side chains of the proteins and lipidic chains (67.61-180.2 $\left.\mathrm{m}^{2} \mathrm{~g}^{-1}\right)$. This result might be attributed that the high extent of protein aggregation in PI caused by extraction process (Shou-Wei et al., 2009).

\section{Conclusions}

The differences in the degree of hydrolysis (DH) according to hydrolysis time and enzymatic system concentration produced limited and extensive hydrolysates from $P$. lunatus. Limited hydrolysates showed a synergistic effect of surface hydrophobicity and amino acid composition, which contributes to equilibrating the hydrophilic/hydrophobic balance, promoting increased solubility of the hydrolysate at the $\mathrm{pH}$ evaluated. As for surface properties, emulsifying properties were more suitable than foaming properties due to hydrophobic/ hydrophilic balance. Extensive hydrolysis generated low molecular weight peptides with hydrophobic amino acid residues, which are associated with structural patterns with interaction at active ACE sites and radicals to generate inhibitory bioactivity. The results obtained in this study support the potential use of limited and extensive hydrolysates from $P$. lunatus in food formulations. 


\section{Acknowledgements}

This research was supported by the CONACYT through project No. 106605 and Doctoral scholarship No. 99406. We are grateful for the scholarship from the PIFI of IPN.

\section{References}

Adebiyi, A. P., Adebiyi, A. O., Ogawa, T., \& Muramoto, K. (2009). Purification and characterisation of antioxidative peptides from unfractionated rice bran protein hydrolysates. International Journal of Food Science Technology, 43(1), 35-43. http://dx.doi.org/10.1111/ j.1365-2621.2006.01379.x

Alaiz, M., Navarro, J. L., Girón, J., \& Vioque, E. (1992). Amino acid analysis by high-performance liquid chromatography after derivatization with diethyl ethoxymethylenemalonate. Journal of Chromatography A, 591(1-2), 181-186. http://dx.doi. org/10.1016/0021-9673(92)80236-N

Association of Official Analytical Chemists - AOAC. (1997). Official methods of analysis of the AOAC. 17th ed. Washington: US Government Printing Office.

Benítez, R., Ibarz, A., \& Pagan, J. (2008). Hidrolizados de proteína: procesos y aplicaciones. Acta Bioquímica Clínica Latinoamericana, 42(2), 227-236.

Betancur-Ancona, D., Martínez-Rosado, R., Corona-Cruz, A., Castellanos-Ruelas, A., Jaramillo-Flores, M. E., \& Chel-Guerrero, L. (2009). Functional properties of hydrolysates from Phaseolus lunatus seeds. International Journal of Food Science and Technology, 44(1), 128-137. http://dx.doi.org/10.1111/j.1365-2621.2007.01690.x

Carrasco-Castilla, J., Hernández-Álvarez, A. J., Jiménez-Martínez, C., Jacinto-Hernández, C., Alaiz, M., Girón-Calle, J., Vioque, J., \& Dávila-Ortíz, G. (2012). Antioxidant and metal chelating activities of Phaseolus vulgaris L. var. Jamapa protein isolates, phaseolin and lectin hydrolysates. Food Chemistry, 131(4), 1157-1164. http:// dx.doi.org/10.1016/j.foodchem.2011.09.084

Chabanon, G., Chevalot, I., Framboisier, X., Chenu, S., \& Marc, I. (2007). Hydrolysis of rapeseed protein isolates: kinetics, characterization and functional properties of hydrolysates. Process Biochemistry, 42(10), 1419-1428. http://dx.doi.org/10.1016/j.procbio.2007.07.009

Chau, CF., Cheung, PCK., \& Wong YS. (1997). Functional properties of protein concentrates from three Chinese indigenous legume seeds. Journal of Agricultural and Food Chemistry, 45(7), 2500-2503. http:// dx.doi.org/10.1021/jf970047c

Chel-Guerrero, L., Gallegos-Tintoré, S., Martínez-Ayala, A., Castellanos-Ruelas, A., \& Betancur-Ancona, D. (2011). Functional properties of proteins from lima bean (Phaseolus lunatus L.) seeds. Food Science and Technology International, 17(2), 119-126. PMid:21421671. http://dx.doi.org/10.1177/1082013210381433

Chel-Guerero, L., Pérez-Flores, V., Betancur-Ancona, D., \& DávilaOrtiz, G. (2002). Functional properties of flours and protein Iisolates from Phaseolus lunatus and Canavalia ensiformis seeds. Journal of Agricultural Food Chemistry, 50(3), 584-591. http://dx.doi. org/10.1021/jf010778j

Chel-Guerrero, L., Scilingo, A. A., Gallegos-Tintoré, S., Dávila, G., \& Añon, M. C. (2007). Physicochemical and structural characterization of Lima Bean (Phaseolus lunatus) globulins. LWT - Food Science and Technology, 40(9), 1537-1544. http://dx.doi. org/10.1016/j.lwt.2006.11.014

Chen, Z.-Y., Peng, C., Jiao, R., Wong, Y.M., Yang, N., \& Huang, Y. (2009). Anti-hypertensive nutraceuticals and functional foods.
Journal of Agricultural and Food Chemistry, 57(11), 4485-4499. PMid:19422223. http://dx.doi.org/10.1021/jf900803r

Cheng, Y., Xiong, Y. L., \& Chen, J. (2010). Antioxidant and emulsifying properties of potato protein hydrolysate in soybean oil-in-water emulsions. Food Chemistry, 120(1), 101-108. http://dx.doi. org/10.1016/j.foodchem.2009.09.077

Cheung, H. S., Wang, F. L., Ondetti, M. A., Sabo, E. F., \& Cushman, D. W. (1980). Binding of peptide substrates and inhibitors of angiotensin-converting enzyme. Importance of the $\mathrm{COOH}$-terminal dipeptide sequence. The Journal of Biology Chemistry, 255(2), 401407. PMid:6243277.

Cian, R. E., Luggren, P., \& Drago, S. R. (2011). Effect of extrusion process on antioxidant and ACE inhibition properties from bovine haemoglobin concentrate hydrolysates incorporated into expanded maize products. International Journal of Food Science and Nutrition, 62(7), 774-780. http://dx.doi.org/10.3109/09637486.2011.582034

Damodaran, S. (1994). Structure-function relationship of food proteins. In N. S. Hettiarachchy \& G. R. Ziegler (Eds.), Protein fuctionality in food systems. New York: Marcel Dekker. p. 190-225.

Food and Agriculture Organization - FAO \& World Health Organization - WHO. (2007). Protein and amino acid requirements in human nutrition. Geneva: WHO. Technical Repor Series 935.

Fitzgerald, R. J., \& O'cuinn, G. (2006). Enzymatic debittering of food protein hydrolysates. Biotechnology Advances, 24(2), 234-237. PMid:16386868. http://dx.doi.org/10.1016/j.biotechadv.2005.11.002

Guimarães, R. C. A., Favaro, S. P., Souza, A. D. V., Soares, C. M., Nunes, A. A., Oliveira, C. S. L., \& Honer, R. M. (2012). Thermal properties of defatted meal, concentrate, and protein isolate of baru nuts (Dipteryx alata Vog.). Ciência e Tecnologia de Alimentos, 32(1), 52-55. http:// dx.doi.org/10.1590/S0101-20612012005000031

Kain, R. J., Zhengxing, C., Tamba, S. S., \& Abu-Kpawoh, J. C. (2009). Study on the effects of enzymatic hydrolysis on the physical, functional and chemical properties of peanut protein isolates extracted from defatted heat pressed peanut meal flour (Arachis hypogaea L.). Pakistan Journal of Nutrition, 8(6), 818-825.

Kato, A., \& Nakai, S. (1980). Hydrophobicity determined by a fluorescence probe method and its correlation with surface properties of proteins. BBA-Protein Structure and Molecular Enzymology, 624(1), 13-20. PMid:7407231.

Komplong, V., Benjakul, S., Kantachote, D., \& Shahidi, F. (2007). Antioxidative activity and functional properties of protein hydrolysate of yellow stripe trevally (Selaroides leptolepsis) as influenced by the degree of hydrolysis and enzyme type. Food Chemistry, 102(4), 1317-1327. http://dx.doi.org/10.1016/j. foodchem.2006.07.016

Larré, C., Mulder, W., Sánchez-Vioque, R., Lazko, J., Bérot, S., Guéguen, J., \& Popineau, Y. (2006). Characterisation and foaming properties of hydrolysates derived from rapeseed isolate. Colloids and Surfaces B: Biointerfaces, 49(1), 40-48. PMid:16581234. http://dx.doi. org/10.1016/j.colsurfb.2006.02.009

Li, G. H., Le, G. W., Liu, H., \& Shi, Y. H. (2005). Mung-bean protein hydrolysates obtained with alcalase exhibit angiotensin I-converting wnzyme inhibitory activity. Food Science and Technology International, 11(4), 281-287. http://dx.doi. org/10.1177/1082013205056781

Liu, Q., Kong, B., Xiong, Y. L., \& Xia, X. (2010). Antioxidant activity and functional properties of porcine plasma protein hydrolysate as influenced by the degree of hydrolysis. Food Chemistry, 118(2), 403-410. http://dx.doi.org/10.1016/j.foodchem.2009.05.013 
Liu, Y., Zhao, G., Ren, J., Zhao, M., \& Yang, B. (2011). Effect of denaturation during extraction on the conformational and functional properties of peanut protein isolate. Innovative Food Science and Emerging Technology, 12(3), 375-380. http://dx.doi. org/10.1016/j.ifset.2011.01.012

Mallikarjun, K. G. G., Gowda, L. R., Rao, A. G., \& Prakash, V. (2006). Angiotensin I-converting enzyme inhibitory peptide derived from glycinin, the 11S globulin of soybean (Glycine max). Journal of Agricultural and Food Chemistry, 54(13), 4568-4573. PMid:16786999. http://dx.doi.org/10.1021/jf060264q

Megías, C., Yust, M. D. M., Pedroche, J., Lquari, H., Girón-Calle, J., Alaiz, M., Millán, F., \& Vioque, J. (2004). Purification of an ACE inhibitory peptide after hydrolysis of sunflower (Helianthus annuus L.) protein isolates. Journal of Agricultural and Food Chemistry, 52(7), 928-1932. PMid:15053531. http://dx.doi.org/10.1021/ jf034707r

Molina, S. E., \& Añon, M. C. (2001). Analysis of products, mechanisms of reaction, and some functional properties of soy protein hydrolysates. Journal of the American Oil Chemists' Society, 77(12), 1293-1301. http://dx.doi.org/10.1007/s11746-000-0204-4

Mugendi, J. B. W., Njangi, E. N. M., Kuria, E. N., Mwasaru, M. A., Mureithi, J. G., \& Apostolides, Z. (2010). Nutritional quality and physicochemical properties of Mucuna bean (Mucuna pruriens L.) protein isolates. International Food Research Journal, 17, 357-366.

Mulero, J., Zafrilla, P., Martínez-Cachá, A., Leal, M., \& Abellán, J. (2011). Péptidos bioactivos. Clínica e Ingestigación en Arterioesclerosis, 23(5), 219-227. http://dx.doi.org/10.1016/j.arteri.2011.04.004

Nielsen, P. M., Petersen, D., \& Dambmann. C. (2001). Improved method for determining food protein degree of hydrolysis. Journal of Food Science, 66(5), 642-646. http://dx.doi.org/10.1111/j.1365-2621.2001. tb04614.x

Pazinatto, C., Malta, L. G., Pastore, G. M., \& Maria Netto, F. (2013). Antioxidant capacity of amaranth products: effects of thermal and enzymatic treatments. Food Science and Technology, 33(3), 485493. http://dx.doi.org/10.1590/S0101-20612013005000076

Pearce, K. N., \& Kinsella, J. E. (1978). Emulsifying properties of proteins: evaluation of a turbidimetric technique. Journal of Agricultural and Food Chemistry, 26(3), 716-723. http://dx.doi. org/10.1021/jf60217a041

Peña-Ramos, E. A., \& Xiong, Y. L. (2002). Antioxidant activity of soy protein hydrolysates in a liposomal system. Journal of Food Science, 67(8), 2952-2956. http://dx.doi.org/10.1111/j.1365-2621.2002. tb08844.x

Pukalskas, A., Van Beek, T. A., Venskutonis, R. P., Linssen, J. P., Van Veldhuizen, A., \& Groot, A. (2002). Identification of radical scavengers in sweet grass (Hierochloe odorata). Journal of Agricultural and Food Chemistry, 50(10), 2914-2919. PMid:11982419. http:// dx.doi.org/10.1021/jf011016r

Ruiz-Ruiz, J., Segura-Campos, M., Betancur-Ancona, D., \& ChelGuerrero, L. (2013a). Encapsulation of Phaseolus lunatus protein hydrolysate with angiotensin-converting enzyme ihibitory activity. ISNR Biotechnology, 37(1), 26-35.
Ruiz-Ruiz, J., Dávila-Ortíz, G., Chel-Guerrero, L., \& Betancur-Ancona, D. (2013b). Angiotensin I-converting enzyme inhibitory and antioxidant peptide fractions from hard-to-cook bean enzymatic hydrolysates. Journal of Food Biochemistry, 37(1), 26-35. http:// dx.doi.org/10.1111/j.1745-4514.2011.00594.x

Schagger, H., \& Von Jagow, G. (1987). Tricine-sodium dodecyl sulfatepolyacrylamide gel electrophoresis for the separation of proteins in the range from 1 to $100 \mathrm{kDa}$. Analytical Biochemistry, 166(2), 368-379. http://dx.doi.org/10.1016/0003-2697(87)90587-2

Shou-Wei, Y., Chuan-He, T., Qi-Bao, W., \& Xiao-Quan, Y. (2009). Functional and conformational properties of phaseolin (Phaseolus vulgaris $\mathrm{L}$.) and kidney bean protein isolate: a comparative study. Journal of the Science of Food Agriculture, 90(4), 599-607.

Tang, C. H., \& Sun, X. (2011). A comparative study of physicochemical and conformational properties in three vicilins from Phaseolus legumes: implications for the Structure-function Relationship. Food Hydrocolloids, 25(3), 315-324. http://dx.doi.org/10.1016/j. foodhyd.2010.06.009

Torruco-Uco, J., Chel-Guerrero, L., Martínez-Ayala, A., Dávila-Ortíz, G., \& Betancur-Ancona, D. (2009). Angiotensin-I converting enzyme inhibitory and antioxidant activities of protein hydrolysates from Phaseolus lunatus and Phaseolus vulgaris seeds. LWT - Food Science and Technology, 42(10), 1597-1604. http://dx.doi. org/10.1016/j.lwt.2009.06.006

Were, L., Hettiarachchy, N. S., \& Kalapathy, U. (1997). Modified soy proteins with improved foaming and water hydration properties. Journal of Food Science, 62(4), 821-824. http://dx.doi. org/10.1111/j.1365-2621.1997.tb15463.X

Yang, H.-Y., Yang, S.-C., Chen, J.-R., Tzeng, Y.-H., \& Han, B.-C. (2004). Soyabean protein hydrolysate prevents the development of hypertension in spontaneously hypertensive rats. British Journal of Nutrition, 92(3), 507-512. PMid:15469655. http://dx.doi. org/10.1079/BJN20041218

Yust, M. D. M., Pedroche, J., Girón-Calle, J., Alaiz, M., Millán, F., \& Vioque J. (2003). Production of ace inhibitory peptides by digestion of chickpea legumin with alcalase. Food Chemistry, 81(3), 363-369. http://dx.doi.org/10.1016/S0308-8146(02)00431-4

Zhang, J., Shi, J., Ilic, S., Xue, S. J., \& Kakuda, Y. (2008). Biological properties and characterization of lectin from red kidney bean (Phaseolus vulgaris). Food Reviews International, 25(1), 12-27. http:// dx.doi.org/10.1080/87559120802458115

Zhao, G., Liu, Y., Zhao, M., Ren, J., \& Yang, B. (2011). Enzymatic hydrolysis and their effects on conformational and functional properties of peanut protein isolate. Food Chemistry, 127(4), 14381443. http://dx.doi.org/10.1016/j.foodchem.2011.01.046

Zhao, Q., Xiong, H., Selomulya, C., Chen, X. D., Zhong, H., Wang, S., Sun, W., \& Zhou, Q. (2012). Enzymatic hydrolysis of rice dreg protein: effects of enzyme type on the functional properties and antioxidant activities of recovered proteins. Food Chemistry, 134(3), 1360-1367. PMid:25005954. http://dx.doi.org/10.1016/j. foodchem.2012.03.033 